\title{
Conflictological Model of Institutionalization of Economic Processes in the Agriculture
}

\author{
Halyna Pohrishchuk ${ }^{1}$, Volodymyr Semtsov ${ }^{1}$, Nataliia Dobizha ${ }^{1}$, \\ Anatolii Kucher $^{2}$, Inna Sysoieva ${ }^{1}$ \\ ${ }^{1}$ Vinnytsia Educative and Research Institute of West Ukrainian National University, \\ Honty, 37, Vinnytsia 21017, Ukraine \\ ${ }^{2}$ V. N. Karazin Kharkiv National University, Svobody Sq., 4, Kharkiv, 61022, Ukraine
}

\begin{abstract}
The institutional essence, structure and typology of conflicts in a market economy are determined. The components of typical conflicts have been studied, as well as analysis of the type of economic conflicts "power - business entities" in the agricultural sector. It is established that any disproportions of the socio-economic system lead, due to the relevant incidents, to the aggravation of conflict situations. It was found that the conflict situations are objectively based on the contradictions of the interests of the main groups of agents and, accordingly, the institutions of the system. The results of our research give grounds to assert that the institutional modernization of the agricultural sector is possible only if new types are prevented and the consequences of existing conflicts are reduced, which is a kind of scheme of evasion within public control. It is proved that one of the universal tools of the unobserved economy in the light of the conflict paradigm are certain types of institutional agreements, and this is a fundamentally new methodology for reflecting real processes.
\end{abstract}

Keywords - conflict, enterprise, modernization, institute, agrarian sphere, management.

DOI: 10.18421/TEM104-44

https://doi.org/10.18421/TEM104-44

Corresponding author: Anatolii Kucher,

V. N. Karazin Kharkiv National University, Kharkiv,

Ukraine.

Email: kucher@karazin.ua

Received: 16 August 2021.

Revised: 02 November 2021.

Accepted: 08 November 2021.

Published: 26 November 2021.

(cc)BY-NC-ND(C) 2021 Halyna Pohrishchuk et al; published by UIKTEN. This work is licensed under the Creative Commons Attribution-NonCommercial-NoDerivs 4.0 License.

The article is published with Open Access at www.temjournal.com

\section{Introduction}

An important reserve for socio-economic development of the country is the improvement of conflict management processes. In recent years, modeling of institutional economic processes has evolved into complex probabilistic systems. The complexity of the information structure of economic decision-making contributes to the spread of conflicts of interest and manifestations of dysfunctional behavior patterns within economic agent groups, both at the national and sectoral levels. In addition, the incompleteness of the institutionalization of the economy determines new tasks and prospects for creating a socio-managerial complex that can identify modern conflicts and related dysfunctions.

Suffice it to note that conflict theory can serve as a tool for improving the main models of economic behavior in the context of countering market agents. We find the conflictological organism the most reasonable for the analysis of diverse socioeconomic problems. It is represented in the dialectical theory of conflict and conflict functionalism. This approach can be fairly considered as one that has been little studied.

It is obvious that any non-antagonistic conflicts, acting as a subjective component of contradictions, are extremely useful in the context of development, provided that they do not endanger the functioning of the entire system. The interpretation of the scientific basis of the above problems is based primarily on the fundamental works on the evolution of conflict theory by such scientists as R. Colloredo-Mansfeld et al. [1], M. Weber [2], V. Pareto [3], E. Kimbrough et al. [4] and others, where conflict, as a rule, was considered as a positive function to ensure the effective functioning of socio-economic systems. The formation of theoretical, methodological and applied foundations of the general conflict theory is also associated with scientific works of M. Alazemi, A. Mohiuddin [5], I. Barinaga-Rementeria, O. Garcia [6] and others 
who considered conflicts through the prism of competition for limited resources.

It is important to note that in general, during the XX-XXI centuries, the attitude to the category of "conflict" has acquired extremely differentiated features, in other words, conflict situations have begun to be studied not only within the framework of destructive power, but also as a factor of constructive adaptation of subjects of socioeconomic relations, by the way, a detailed analysis of this phenomenon is presented in [7], [8], [9].

Modern analysis of conflicts in the economy, usually, is aimed at studying their dynamics, while it is obvious that the formation of constructive economic processes by identifying conflictological models of institutionalization is possible only on the basis of authentication of axiological trends in the emergence and development of conflict situations. Despite considerable research, there is still an urgent need to develop and model institutional technologies to modernize economic relations, including those in the agricultural sector of Ukraine.

\section{Materials and Methods}

The aim of the article is to identify the main nonantagonistic conflicts arising in the market environment of the agricultural sector of Ukraine in order to develop an effective mechanism for organizational and institutional changes and search for additional socio-economic opportunities and reserves.

The paper uses general scientific methods and specific methods of economic research, in particular, the induction, deduction, analysis and synthesis to develop universal scheme of conflict structure and typology, systematization of the main conflict factors of the modern agricultural sector of Ukraine; methods of formalization and conceptualization for cybernetic description of the approach based on the system paradigm of oscillation effects, catastrophic changes, and synergy is proposed for conflict dynamics.

\section{Results and Discussion}

We are convinced that the methodological basis for considering socio-economic problems from the point of view of a universal model of conflict formation and implementation can be considered as a set of basic provisions of the general theory of conflicts. It is also quite obvious that the identification of the potential of non-antagonistic conflicts is a determinant of the development of almost any socio-economic system [7].

It is fair to note that nowadays neither a domestic nor foreign science have given a clear definition of the concept of "conflict". So, for example, $\mathrm{V}$. Nagaev claimed, that functional conflict is a signal of turmoil and the need to find a new optimal solution [8]. K. Levin understood "conflict" as a situation when an individual is simultaneously affected by two forces of approximately the same magnitude, but directed in the opposite direction [9]. Besides, a somewhat similar opinion is shared by I. Groshev, who, studying the features of behavior during conflicts notes that conflict is a single triple system of "subjects - interests actions", which is based on subject relations [10].

Suffice it to note that the definition of conflict provided by M. Nesprava is extremely close to our understanding, according to which "aggravation of contradictions arising from differences in the views, interests, aspirations of people, which are perceived and evaluated by its participants as incompatible with their own" [11]. Emphasizing the complexity of the issue of identifying the essence of conflict, T. Gorobets wrote that "conflict is a very complex social and psychological phenomenon, which is understood as the most acute way to eliminate contradictions that arise in the process of interaction, and consists in countering the subjects of conflict and is accompanied by emotions with a negative modality" [12].

There is also uncertainty and confusion about the category of "conflict situation". Thus, M. Tevosyan wrote that "a procedural complex formed from the processes of reorganization of activities in connection with new circumstances, the design of new objects of activity for their transformation, mobilization of resources for mastering the situation" [13]. Meanwhile, L. Tsoi, studying the theory and practice of conflictology, argued that "the concept of conflict situation is broader than conflict, and includes three stages: pre-conflict, conflict and post-conflict situation. A conflict situation is an unbalanced and potentially contradictory situation" [14]. Obviously, such facts about different approaches require concentration and thoughtfulness.

Therefore, analyzing a specific conflict situation, it should be assumed that any conflict consists of a conflict situation and an incident [15]. We are convinced that an incident should be understood as the deterministic behavior of a participant (or participants) in a conflict, which is aimed at achieving specific goals. We recognize that an incident itself can only arise as a result of a conflict situation. Therefore, in our opinion, for the management system it is important to identify incidents that can be interpreted as indicators of conflict, since this will contribute to the rational use of resources and maximize the overall cost.

It is worth noting that qualitative identification of the essence of conflict occurrence is possible after its main components are determined; such a scheme is proposed in Figure 1. 


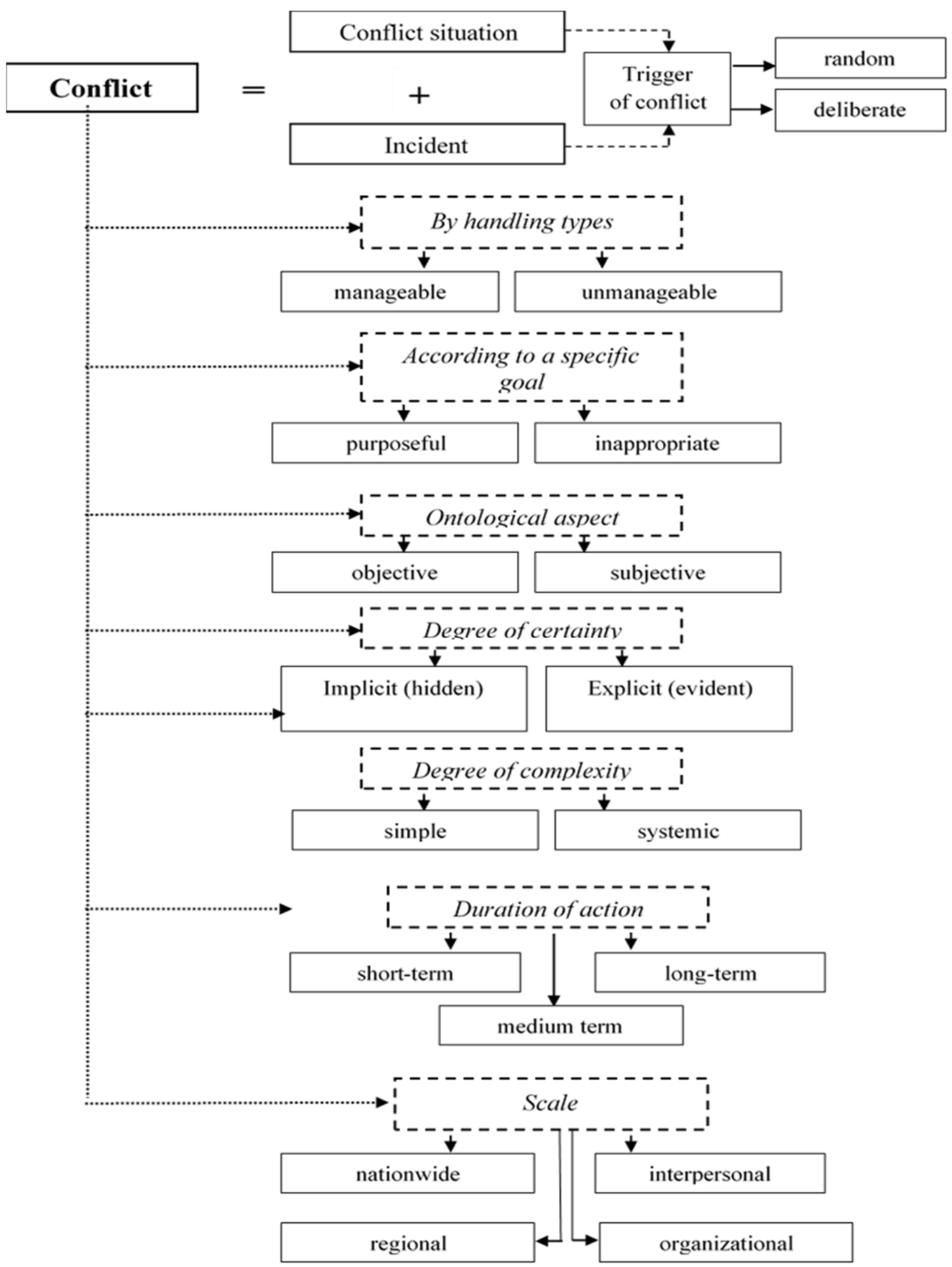

Figure 1. Universal scheme of conflict structure and typology Source. Author's interpretation of works [9], [10], [12], [16].

The need for institutional changes in the domestic agricultural sector looks quite natural and quite understandable. We can consider and understand: the general formulation of the issue is that institutional (in the scientific literature, the term "institutional" is also used) theory is contrasted as one that can really explain the shortcomings of the existing society, that is, the capitalist system that dominates the world today. It should be understood that when determining the goals and measures of institutional modernization of the agricultural sector, the authorities need to proceed from the real opportunities and economic condition and take into account that certain institutions or their insufficient organization (i.e., a specific institutional environment) can slow down innovation. Hence, correction and control of institutional development should be implemented in such a way as to 
coordinate the interests, if not of the entire society, then at least the benefits of the main participants in economic relations, who are obvious and/or potential recipients.
Thus, a scientific analysis of a problem complex in the agricultural sector, as well as a critical understanding of the experience of economic agents functioning, enabled us to systematize and generalize the main conflict factors in the domestic agricultural sector of the economy (Figure 2).

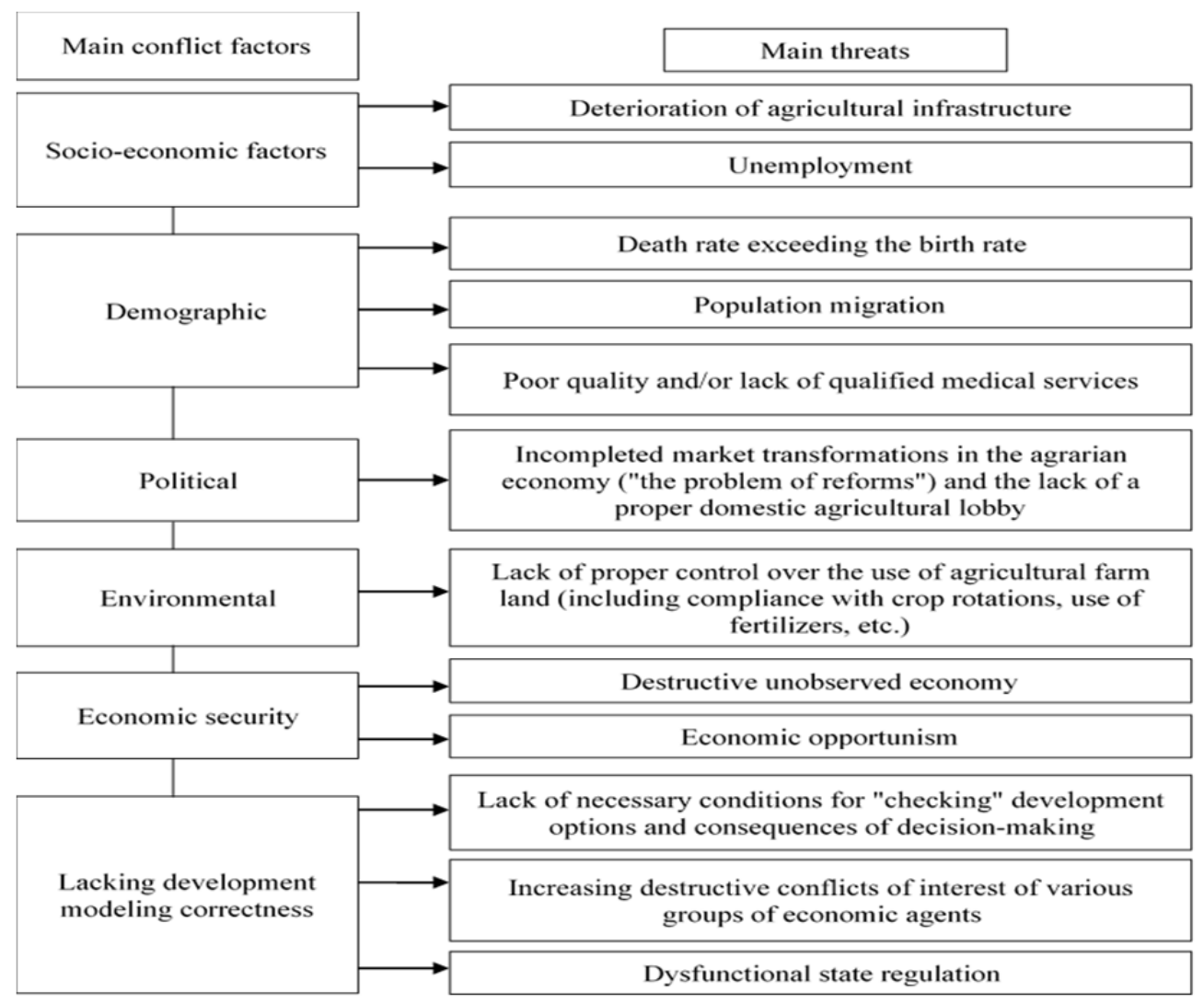

Figure 2. Systematization of the main conflict factors of the modern agricultural sector of Ukraine Notes: the division into factors is conditional, because in real life they are interrelated. Source. Author's development.

We emphasize that we have focused on the analysis of conflict factors related to ensuring economic security that arose in 2010-2020 in the agricultural sector of the Ukrainian economy. It is impossible to neglect the fact that this particular conflict aspect of the agricultural sector is characterized by well-established crisis development trends, which in turn is accompanied by a number of dysfunctional socio-economic phenomena.

Identification within the framework of real phenomena indicates a regularity of correlation between the observed economy and unobserved economic processes as a function of a specific socio-economic institutional environment and an integral immanent factor of administratively regulated economies. Suffice it to present the results of an analysis of such typical conflicts. Thus, according to the authorities [17], in 2020, the tax debt to the consolidated budget in Vinnytsia region made up 1065 million $\mathrm{UAH}$, including almost 475.6 million UAH of bankrupt business entities debts (besides, market agents owed to the state budget about 605.2 million UAH, and almost 459.8 million UAH to local budgets).

It is necessary to note that as of $01.05 .2020,2733$ enterprises (legal entities) and 19714 tax payers (private owners) were debtors to the state and local budgets of the region. In addition, compared to 01.01.2020, the total number of debtors in the Vinnytsia region increased by 1,147 people. Thus, even a superficial analysis of statistical monitoring shows that the impact of some dysfunctions, such as unwillingness of market agents to pay taxes, fees and other mandatory payments, only increases.

Taking into account the above-mentioned information, we would like to emphasize that the problem in the agricultural sector as a result of providing tax incentives has almost always had a national scale. For example, in 2014, more than 16 thousand business entities in the country were under special taxation regulations of agricultural activities. At the same time, in 2014, these market agents according to their VAT declarations made 
up a tax credit amounting almost 11.2 billion UAH for more than 92 thousand business entities liable to the general tax system.

Although, starting from $1^{\text {st }}$ of January 2017, the special VAT regime was replaced with benefits for individual agricultural producers, however, the problem of unobserved economic processes remained unchanged. It is obvious that by abolishing some privileges in the agricultural sector (FAT, financial assistance, special VAT payment regime), the authorities automatically introduce other prerogatives (single tax, VAT exemption for the export of oilseeds outside the customs territory of Ukraine [18], support for animal husbandry (bank loans, compensation for the construction and reconstruction of livestock complexes, etc. [19]).

Paradoxically, quite often the authorities themselves indirectly stimulate unobserved economic processes. For example, in December 2020, when taking measures aimed at supporting domestic agricultural commodity production in Ukraine, a reduced VAT rate (from $20 \%$ to $14 \%$ ) was introduced for operations on supply of certain agricultural products to the customs territory of Ukraine and importation into the customs territory of Ukraine [20].

We believe that this situation is an example of incorrect state regulations. Under such conditions, it is important to create an effective control system over those enterprises whose activities can be assessed as risky. The authorities should pay considerable attention to such indicators of the activity of business entities as establishing real indicators of yield, peculiarities of stock raising, the number of employees, financial capabilities of market agents, the quality and quantity of equipment, etc.

However, until the "nature of conflict" which manifests itself in the form of unobserved economic processes is resolved, we cannot expect to overcome the corresponding socio-economic dysfunctions. The problem with the Ukrainian authorities is that they usually deal with incidents (manifestations), and not with the nature of conflicts.

Empirical analysis shows that the amounts of funds that go to budgets of various levels, as a result of court decisions, are quite often significantly less compared to the amounts of funds that remain at the disposal of business entities. For example, in Vinnytsia region only in the first half of 2020, this difference was more than 5 times, for example, in the first quarter of 2020 , the number of cases resolved in favor of the authorities was - 36 (at a total amount of about 22.3 million UAH), while the number of cases resolved in favor of business entities was - 59 (at a total amount of almost 126.6 million UAH). By the way, it is important to note that the current reviewproceedings on cases, are usually time-consuming and therefore cases can be on appeal and / or cassation appeal. In our understanding, the reasons for such imbalances can be explained by two main theoretical hypotheses: 1) individual representatives of government bodies create biased conflicts, manifested in purposeful and/or inappropriate violation of the norms of current legislation; 2) business entities, using corruption schemes, ensure the adoption of appropriate court decisions in their favor (this effect is described in the literature [21] as a separate example of the implementation of the theory of seizing the state regulator).

It is extremely important to note that during the first quarter of 2020, courts of various instances had to deal with 1 thousand court cases worth almost 1.3 billion UAH referring to market agents in Vinnytsia region only. Under such conditions, taking into account the specifics of Vinnytsia region, its agricultural enterprises have to be specially attended to. For example, in 2020, the judicial authorities of appeal ruled in favor of such payers as Joint LLC "Urozhay" (the number of claims is about 99.2 million UAH), LLC "Ukrainian flour company" (the number of claims is almost 5.9 million UAH), etc.

We are convinced that in the conditions of a budget deficit, it is inappropriate to introduce a judicial mechanism according to which Ukrainian executive authorities, as budget institutions, thus, non-profit market agents, are required to pay a court fee, because transaction costs arise due to the movement of public funds from one budget account to another budget account. Meanwhile, the main problem, in our opinion, is the emergence of a corruption component due to the fact that filing a claim depends on the availability of funds. This enables tax withdrawal authorities, for example, to create working groups that estimate the degree of prospects or futility of a particular claim. The subjectivity and inadequacy of the work of such working groups is obvious, since in the absence of a clear legal framework and methodology for determining the expediency/or inexpediency of appealing court decisions, executive bodies actually get the opportunity to provide "tax indulgences" to business entities. So, there is a potential threat of the so-called "seizure" of the state regulator without formal violation of the law. In addition, such working groups are actually collegial bodies, and therefore, according to the current legislation, it is problematic to determine the degree of guilt in the event of abuse during decision-making.

For example, in 2017, after the courts issued legal decisions regarding taxes payment in favor of 
business entities Farm entity "Falborkovo", LLC "Vinnytsia Poultry Farm", LLC "Poultry Farm Podillia", the authorities, at the meeting of the work group, decided on the expediency of filing an appeal with a request for exemption from paying the court fee in the case of FE "Falborkovo", while in the case of LLC "Vinnytsia poultry farm" and LLC "Poultry Farm Podillia", a decision was made on the expediency of appealing court decisions. It should be noted that sometimes such working groups make decisions on the expediency of filing Cassation complaints with a request to postpone the payment of the court fee, which, by the way, was the case with LLC "Poultry Farm Podillia". Eventually, the courts should consider only those cases in which the court fee was paid, as stipulated by law, and therefore, their behavior model is largely predictable.

In other words, virtually any decision of the work group can be legally justified by the lack of sufficient financial resources for the authorities to pay the court fee. Ukrainian society has recently faced such dangers. One gets the impression that such a logical mismatch can be a conscious behavior pattern in order to make individual market agents influence economic processes. The acquisition of such powers by executive bodies contributes to the "rapprochement" of individual government representatives with business, and also creates conditions for the emergence of hidden economic processes.

Thus, professional experience and skills, access to information and authority, combined with the above-mentioned uncertainty about responsibility, can potentially create conditions for individual civil servants to ignore the interests of the state and develop corruption. The theoretical description, features and consequences of these hazards are not fundamentally new, and therefore are covered in detail in the scientific literature, for example, in the works of L. Kosals [22], V. Tambovtsev [21] and others.

In our opinion, the diagnosis of acute conflict manifestations in the view of wage legalization processes also requires special attention. It is quite obvious that measures to combat salaries "in envelopes" and legalize relations in employment require serious improvements in the agricultural sector.

Analysis of the activities of business entities in domestic agro-industrial production shows that it is the dangers of unobserved economic processes that are now the most common. For example, the Enterprise PE "Mikhalych \& Co" was engaged in the procurement of milk from the population and its processing. Milk was purchased from the population of Vinnytsia, Tyvrovsky, Nemirovsky,
Kalinovsky and Litinsky districts of the Vinnytsia region. The company operated within the framework of the current legislation. However, the following features were observed in the company's activities: 1) the level of tax payment was significantly inadequate to the level of tax payment in the relevant industry; 2) foreign economic (import) operations were carried out through nonresident founders and non-residents registered in offshore zones or countries with a simplified tax regime for indirect deliveries, in significant volumes (more than 100 thousand UAH); 3) relationships were observed with suppliers in which there was a discrepancy between the purchased and sold imported goods (the so-called "Break" of the supply chain), etc.

Another example is PJSC Bershadsky Kombinat, whose main activities were malt production, distillation, rectification and mixing of alcoholic beverages, wholesale and retail trade. It should be noted that this business entity also carried out its activities in accordance with the norms of domestic legislation. However, potential socio-economic threats were observed in economic processes, namely: 1) payment of license payments was made to the account of a non-resident; 2) declaration of net income from the sale of products (goods, works, services) at the level or below the cost of products sold; 3) fairly frequent submission by the payer of clarifying calculations of tax reports on income tax and VAT in the direction of reducing tax liabilities, etc.

It should be noted that the tools of state regulation can be actively used in the context of unobserved economic processes. After all, in conditions of political dysfunctions, individual market agents, covering themselves with the interests of society, get the opportunity to influence the activities of agricultural producers. There are common cases when, during emerging conflicts, attempts are made to initiate inspections of the activities of agricultural business entities by state authorities. For example, in 2018, such inspection was made as a result of an appeal by one of the residents of the village of Kordelevka, Kalinovsky district, Vinnytsia region, to the authorities regarding the activities of the farm "Ukraine" located in the Lipovets District of Vinnytsia region, to check the use of the market of unaccounted land and hidden income by this agent. And although the information about violations by FE "Ukraine" of domestic legislation was not confirmed: this farm paid taxes regularly and in full; the area of leased land plots was declared in the proper way. It is not difficult to see that the mechanism of conducting verification in real life generates transaction losses, and therefore can be successfully used as a means of economic struggle. 
Another example of destructive economic behavior on the territory of the Vinnytsia region: the Company LLC "Dolphin" during its activity interacted with such market agents as LLC "Agrokhimpostach-2003" and LLC "ATZ-Service". LLC ATZ-Service turned out to have been established by unidentified persons and registered as a figurehead for a monetary reward. This can certainly be considered as a cover for unobserved financial and economic activities. Additional social tension is also caused by the fact that now the authorities are not able to fully check the economic activities of LLC "Dolphin", since, as it became known, the financial and economic documentation concerning relations with the enterprises of LLC "Agrokhimpostach-2003" and LLC "ATZ-service" was destroyed as a result of a fire in the premises of the business entity. According to the current legislation, the company was granted a period ( 90 calendar days) to restore the lost (damaged) documentation. However, LLC Dolphin was unable to restore the primary financial and economic documentation within the established time frame. At the same time, the company overestimated the costs accounted when determining the object of taxation, as well as underestimated the payment of VAT. Such cases are quite common.

It is difficult to predict and forecast the development of conflicts between the main participants in socio-economic relations without knowing the basics of institutional rules of behavior. As a methodological principle of responding to conflicts we propose an analog universal model of the dependence of economic behavior on constitutive determinants as the following formula:

$$
P_{n}=f\left(S_{n}, L_{n}\right)
$$

where $\mathrm{S}$ - are exogenous determinants (location, scale, socio-economic status of the conflict opponent, etc.);

L - endogenous (personal, individual) determinants (age, gender, psychoemotional characteristics (perception), etc.
For a cybernetic description an approach based on the system paradigm of oscillation effects, catastrophic changes, and synergy is proposed for such conflict dynamics (Figure 3). The research of I. Groshev [10] can serve as somewhat approximate example of such modeling.

Corresponding to this approach, the conflict is considered as a system implementation (on the principle of "input-processor-output" [23]), functioning under conditions of objective fluctuations, where the latter are carried out under the influence of unique effect-forming factors. At the same time, fluctuations at certain time periods (bifurcation points) can acquire modes of sharp catastrophic changes under the influence of attractors (possible functional factors - vectors of system development that determine its possible changes).

In turn, the dynamics of conflicts can be influenced in different directions simultaneously by both factors of self-organization and the destruction of the system's functioning mode, where they can acquire the character of synergistic reinforcement. The defining thesis of the interpretation of such a description is that socio-economic behavior in each particular case may depend to a greater extent on either endogenous or exogenous determinants.

Thus, if we return to the issue of describing conflicts in the agricultural sector of Ukraine, it becomes quite clear, that the task of any civilized state is to prevent the spontaneous evolution of conflicts, as well as to create appropriate tools for regulating their development in the interests of society. Ensuring an effective conflict management system is possible only using economic and sociopolitical determinants. Although it is difficult to fully determine the vector of evolution of a particular conflict, planning the necessary conditions for this is a mandatory component of ensuring sustainable socio-economic development.

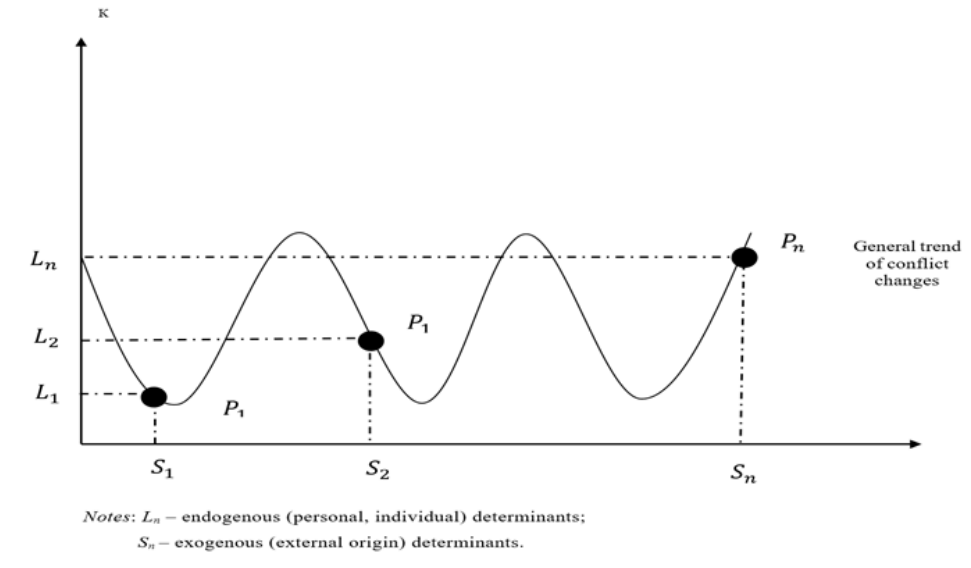

Figure 3. Conceptual description of the conflict dependence model on basal determinants Source. Interpretation of works [10-16]. 
So, the conflictological model of institutionalization of economic processes in the agriculture can be useful in the assessment and analysis of potential risks of audit of agricultural enterprises [24], resolving conflicts between the environmental, economic and/or social components of sustainable competitiveness of agricultural enterprises [25], resolving business conflicts [26] and conflicts in nature management [27]. The application of this model, as well as conflict management in general, requires proper information support [28]. The institutional modernization of the agriculture is possible only if new types are prevented and the consequences of existing conflicts are reduced.

\section{Conclusion}

Thus, any imbalances in the socio-ecological and economic system lead through relevant incidents to conflicts aggravation. The latter are based objectively on the contradiction of the interests of the main groups of agents and institutions of the system. The practice shows that institutional modernization of the agricultural sector is possible only if new types of conflicts are prevented and the consequences of existing conflicts are reduced. Sustainable institutional changes can only be achieved by creating such a condition where the main participants in the conflict have to take into account ("respect") the socio - economic goals of each subject of relations. At the same time, it is the state that should initiate the implementation of the function of coordinating goals, since it can ensure and guarantee compliance with the norms.

In general, conflict characteristics are typical for any socio-economic system. However, it is in transitive economies that indicators of such conflict, types and forms of conflict become particularly important as a direct factor of dysfunctions and the basis for expanding the field of unobserved economic processes. At the same time, the current state of the domestic agricultural sector is characterized by an increased level of conflict. Numerous facts prove that in the context of aggravating socio-economic conflicts in Ukraine, the authorities should not stand aloof, but have to be involved in the real process of forming and controlling the behavior of business entities. Practice also shows that the adequacy of consideration of current socio-economic problems can be ensured by describing the model of relevant conflicts. At the same time, conflict resolution should take place according to a scientifically based system for correcting the behavior model of the main participants in socio-economic relations.

\section{References}

[1]. Colloredo-Mansfeld, R., Ordoñez, A., López, H. P., Quick, J., Quiroga, D., \& Williams, J. (2018). Conflicts, territories, and the institutionalization of post-agrarian economies on an expanding tourist frontier in Quilotoa, Ecuador. World Development, 101, 441-452.

[2]. Weber, M. (2009). The theory of social and economic organization. Simon and Schuster.

[3]. Pareto, V., \& Powers, C. H. (2017). The transformation of democracy. Routledge. https://doi.org/10.4324/9781351302449

[4]. Kimbrough, E. O., Laughren, K., \& Sheremeta, R. (2020). War and conflict in economics: Theories, applications, and recent trends. Journal of Economic Behavior \& Organization, 178, 998-1013. https://doi.org/10.1016/j.jebo.2017.07.026.

[5]. Alazemi, M. K. T. E., \& Mohiuddin, A. K. M. (2020). Conflict management of construction projects - a research. International Journal of Engineering and Advanced Technology, 8(6), 38093817. https://doi.org/10.35940/ijeat.F9396.088619.

[6]. Etxano, I., Barinaga-Rementeria, I., \& Garcia, O. (2018). Conflicting values in rural planning: A multifunctionality approach through social multicriteria evaluation. Sustainability, 10(5), 1431. https://doi.org/10.3390/su1005143.

[7]. Moroz, O. O., Smetanyuk, O. A., \& Lazarchuk, O. V. (2010). Teorija konfliktiv v konteksti pobudovy zaghaljnoji modeli efektyvnosti suchasnogho pidpryjemstva: monoghrafija [Conflict theory in the context of constructing a general model of the efficiency of a modern enterprise]. Vinnitsa, VNTU.

[8]. Nagaev V. M. (2016). Administrative bases of prevention of organizational conflicts in the conditions of agricultural production, Bulletin of KhNAU. Series: Economic Sciences, 2, 126-134.

[9]. Lewin, K. (1948). Resolving social conflicts. New York, McGraw Hill, 230 p.

[10]. Groshev, I. V. (2005). Gendernye polovye i lichnostnye razlichiia povedeniia $\mathrm{V}$ konfliktakh [Gender, sex and personality differences in conflict behavior]. World of psychology, № 2 .

[11]. Nesprava, M. V. (2021). The effectiveness of the Interaction of the Professor with the Staff and Management of the Higher-educational institution: analysis, methods and ways to achieve, Theoretical and applied problems of psychology, 3(56), 34-50, https://doi.org/10.33216/2219-2654-2021-56-3-134-50. [in Ukrainian].

[12]. Gorobec, T. N. (2005). Intrapersonal conflicts as a basic component of self-destructive behavior, The World of Psychology, 2(42), 142-147.

[13]. Tevosyan, M. (2014). The Creative Thinking in a Conflict Situation, WISDOM, 2(1), 127-136, https://doi.org/10.24234/wisdom.v1i2.52.

[14]. Coj, L. N. (2004). Practical conflictology: from Theory to Practice. Moskva, Globus. Russia, 233 p.

[15]. Borodkin, F. M., \& Korjak, N. M. (1989). Attention: Conflict! Novosibirsk, Nauka, Russia, $190 \mathrm{p}$. 
[16]. Ashofteh, P. S., Bozorg-Haddad, O., \& Loáiciga, H. A. (2017). Role of adaptive water resources management policies and strategies in relieving conflicts between water resources and agricultural sector water use caused by climate change. Journal of Irrigation and Drainage Engineering, 143(5), 02516004.

https://doi.org/10.1061/(ASCE)IR.1943$\underline{4774.0001149}$

[17]. The owners of Vinnytsia region owed over 1 billion hryvnias.,(2020). Retrieved from: https://vin.tax.gov.ua/media-ark/newsark/446971.html. [Accessed: 01 August 2021].

[18]. Law of Ukraine., (2018). "On Amendments to Subsection 2 of Section XX "Transitional Provisions" of the Tax Code of Ukraine Concerning Certain Issues of Value Added Taxation of Transactions on Export of Oilseeds from the Customs Territory of Ukraine" № 2440-VIII. (2018, May 22). Retrieved from:

http://zakon.rada.gov.ua/laws/show/2440-19.

[Accessed: 01 August 2021].

[19]. The Resolution of the Cabinet of Ministers of Ukraine., (2018). "On approval of the Procedure for the use of funds provided in the state budget to support the livestock industry" № 107 (2018, February 7). Retrieved from:

https://zakon.rada.gov.ua/laws/show/107-2018-

$\%$ D0\%BF\#Text. [Accessed: 10 August 2021].

[20]. Law of Ukraine.,(2020). "On Amendments to the Tax Code of Ukraine Concerning the Value Added Tax Rate on Transactions for the Supply of Certain Types of Agricultural Products" № 3656. (2020, December 17). Retrieved from: https://www.rada.gov.ua/print/201053.html. [Accessed: 11 August 2021].
[21]. Tambovcev, V. L. (2010). Theory of State Regulation of the Economy. Moscow, Infra-M. $157 \mathrm{p}$. Retrieved from: https://biblioclub.ru/index.php?page=book\&id $=276$ 645 [accessed: 11 August 2021].

[22]. Kosals, L. (1998). Shadow Economy as a Feature of Russian Capitalism, Economic issues, 10, 59-80.

[23]. Baldin, K. V., Vorob'ev, S. N., \& Utkin, V. B. (2014). Management decisions. Moscow, Dashkov i $\mathrm{K}, 496 \mathrm{p}$.

[24]. Sysoieva, I., Zagorodniy, A., Pylypenko, L., Tomilin, O., Balaziuk, O., \& Pohrishchuk, O. (2021). Analysis of potential risks of audit of agricultural enterprises. Agricultural and Resource Economics: International Scientific EJournal, 7(1868-2021-1008), 164-191. https://doi.org/10.51599/are.2021.07.01.09.

[25]. Kucher, A. (2019). Zonal features of formation and reserves of increasing the sustainable competitiveness of agricultural enterprises. Agricultural and Resource Economics: International Scientific E-Journal, 5(3), 77-105. https://doi.org/10.22004/ag.econ.293987.

[26]. Kopytova, I. (2018). Management potential of organizational culture in resolving business conflicts. Agricultural and Resource Economics: International Scientific E-Journal, 4(1), 77-90. https://doi.org/10.22004/ag.econ.270289.

[27]. Fisher, L. A., Kim, Y. S., Latifah, S., \& Mukarom, M. (2017). Managing forest conflicts: perspectives of Indonesia's forest management unit directors. Forest and Society, 8-26. https://doi.org/10.24259/fs.v1i1.772.

[28].Dmytrenko, M. O., Yarmoliuk, F. O., Kudlaieva, N., Sysoieva, I., Borkovska, V., \& Demianyshyna, O. (2020). Application of modern software for improving the economic analysis accounting efficiency at enterprises. Journal of management Information and Decision Sciences, 23(5), 649-660. 